\title{
Geological-Geophysical Investigations for Hydrological Studies in a Basement Complex Terrain, Southwestern Nigeria
}

\author{
Kehinde D. Oyeyemi, Ahzegbobor P. Aizebeokhai, \\ and Oluseun A. Sanuade
}

\begin{abstract}
Geological field mapping and vertical electrical soundings (VES) were conducted in Igbo-Ora, southwestern Nigeria in order to unravel the subsurface structures, as part of the preliminary investigations for groundwater resources assessment, development and management in a crystalline basement terrain, southwestern Nigeria. The geological survey was carried out to produce a local geological map with spatial distributions of different basement rocks and their structural trends. Metamorphic and igneous rocks make up 90 and 10\%, respectively, of the rocks in the study area. They include the banded gneiss, biotite granite gneiss, quartzite/quartz-schist and granitic intrusions of varying grain sizes. Twenty-five VES surveys were conducted within the biotite granite gneiss terrain of the area, using Schlumberger array, providing layering and geoelectrical parameters. Three geoelectric layers delineated from the VES 1D inversion models are clayey sand/sandy clay top soil (overburden), partly weathered or fractured basement and fresh basement. The corresponding inverse model resistivity values ranges are: 209.7-2298.0, 45.1-346.2 and 1013.7-33,124.0 $\Omega \mathrm{m}$ with bottom depths ranges of $0.9-2.9$ and $4.6-42.0 \mathrm{~m}$, respectively. The topmost clayey sand/sandy clay layer will serve as the protective layer, while the saturated portion of the partly weathered or fractured basement, at depth, favors groundwater exploration and development in the study area.
\end{abstract}

\section{Keywords}

Geologic field mapping • Basement terrain • Geophysical survey $\bullet$ Groundwater exploration • Southwestern Nigeria

K. D. Oyeyemi $(\varangle) \cdot$ A. P. Aizebeokhai Applied Geophysics Unit, College of Science and Technology, Covenant University, Ota, Nigeria

e-mail: kehinde.oyeyemi@covenantuniversity.edu.ng

O. A. Sanuade

Department of Geosciences, King Fahd University of Petroleum and Minerals, Dhahran, Saudi Arabia

\section{Introduction}

The exploration of groundwater is of necessity due to the limitation in the amount of surface water available for domestic, industrial and agricultural use in the face of the continual rise in population and climate change. The successful exploration and exploitation of groundwater within the complex basement aquifers requires a proper understanding of their geohydrological characteristics. Availability of groundwater resources within the complex crystalline basement terrain depends largely on the secondary porosity due to weathering, jointing, and fracturing. Several researches have been carried out on the application of geoelectrical resistivity techniques in the evaluation, exploration and exploitation of groundwater in southwestern Nigeria [1-8]. These geoelectrical resistivity surveys entail the estimation of spatial and/or temporal variability of subsurface electrical properties, which include resistivity, conductivity and dielectric constant [5]. In this research, a geologic constrained geoelectrical method was adopted for subsurface characterization in a crystalline basement terrain for groundwater potential in the study area. The study is directed towards the reduction of the risks associated with dry boreholes drilling as a result of poor groundwater exploitation in a complex basement terrain.

\section{Materials and Methods}

The location of this study is Temidire village and its environs, Igbo-Ora, Southwestern Nigeria. The area falls within the basement complex of southern Nigeria, which is located in the Dahomeyide section of the pan Africa mobiles belt. The geological field mapping involved the systematic study of rock outcrops within the area covering $7^{\circ} 25^{\prime}-7^{\circ} 30^{\prime} \mathrm{N}$ latitude and $3^{\circ} 25^{\prime}-3^{\circ} 30^{\prime}$ E longitude within the Abeokuta sheet. The samples of rocks were chipped out for megascopic identification. The orientations (strike and dip) of 
various structural features on rock outcrops such as joints, foliations and mineral lineations were measured using compass clinometer and then recorded. Samples of rocks collected from different outcrops were cut into smaller fragments and polished on slides, to make thin sections of rocks that were observed under a petrographic microscope. Twenty-five resistivity soundings were conducted in NS-SW direction (Fig. 1a) with maximum half-current electrode spread $(\mathrm{AB} / 2)$ of $100 \mathrm{~m}$, sufficient for the anticipated depth of investigation (DOI). The VES points spacing interval is $50 \mathrm{~m}$.

\section{Results}

The rocks' petrological studies show the outcrops to be banded gneiss, biotite granite gneiss, quartzite and granite in that chronological order (Fig. 1b). Also, the structural features associated with rocks in the area are joint (trending NE-SW), fault (NEE-SWW), veins and veinlets (NWW-SEE), folds (NWW-SEE) and foliations (NWW-SEE). The geoelectric parameters obtained from the computer iterations of the resistivity soundings are presented in Fig. 1c, d. Three geoelectrical layers were delineated from the iterated curves and presented in Fig. 2. A large consistency of the geoelectric parameters was observed among the VES curves. Based on the local geology of the study area and the available information from the boreholes and hand-dug wells, the delineated layers are: overburden layer (mainly sandy clay units) with model apparent resistivity ranging between 209.7 and $2298.0 \Omega \mathrm{m}$, with a thickness range of $0.9-2.9 \mathrm{~m}$; intercalation of partly weathered and fractured basements with model resistivity range of 45.1-346.2 $\Omega \mathrm{m}$, with a thickness range of 4.6$42.0 \mathrm{~m}$; fresh basement with model resistivity ranging from 1013.7 to $33,124.0 \Omega \mathrm{m}$. (a)

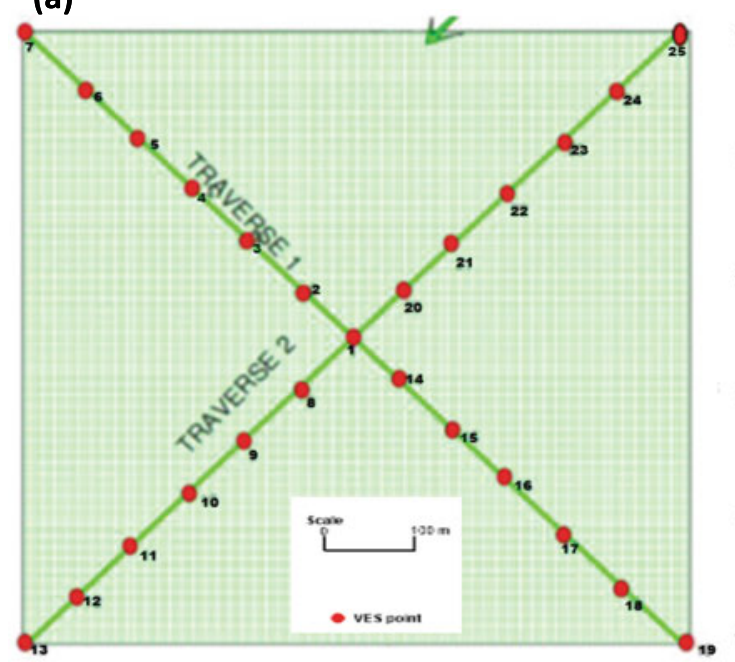

(b)

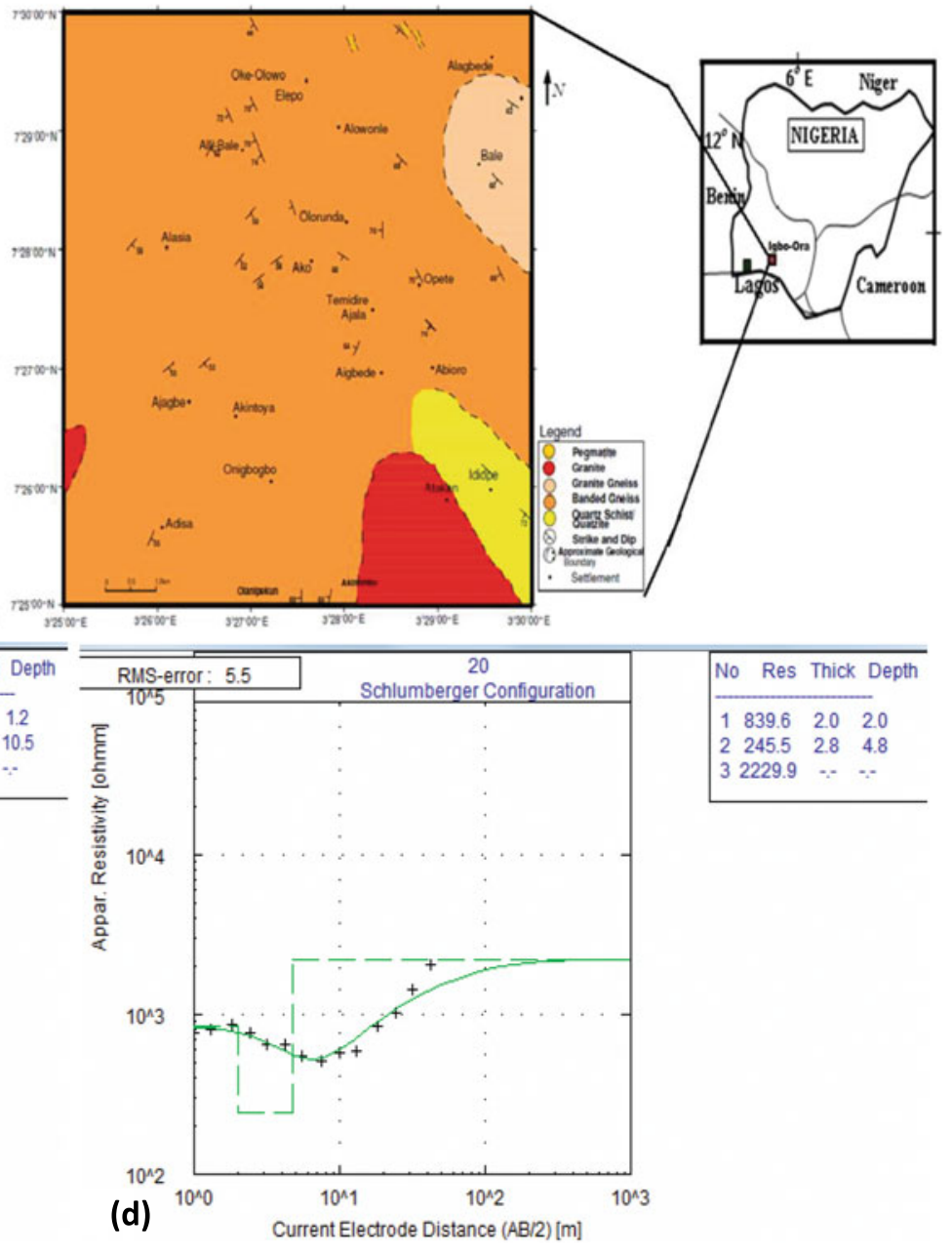

(c)

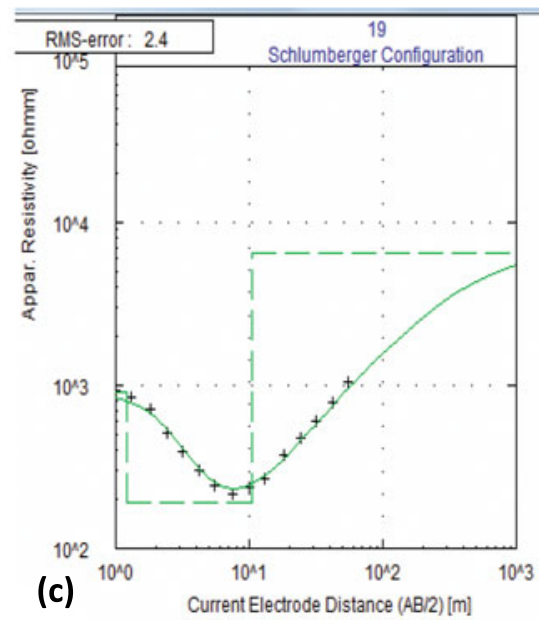

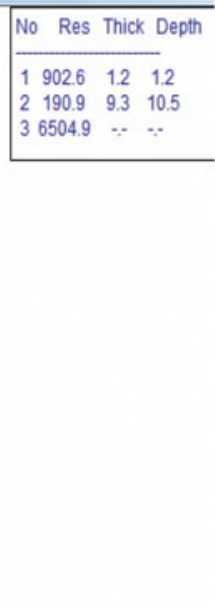

Fig. 1 a Survey basemap b Geologic map of the study area, c and d Representative VES inversion models 
Fig. 2 Representative geoelectric section constructed from the VES results

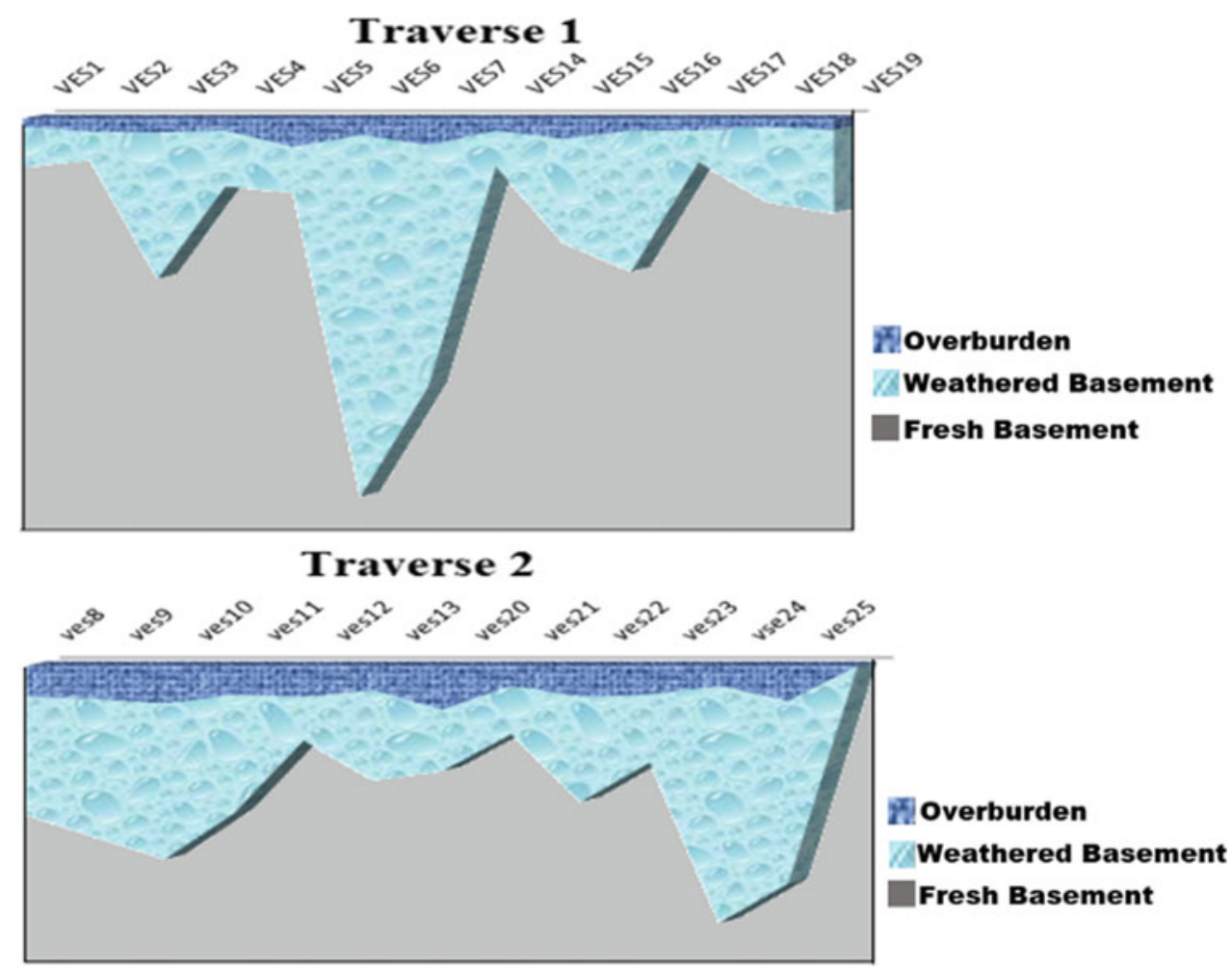

\section{Discussion}

Considering the groundwater exploration in hard terrain, the essential factors are basement architecture and fracture depths [9]. The variation in the model resistivity values of $1 \mathrm{D}$ sounding resistivity models depicts the inhomogeneity of the overburden with clay contents in the study area. The degrees of homogeneity and of thickness of the overburden are important groundwater indices. The thickening of overburden materials in the study area is favorable to the mapping of groundwater aquiferous zones in a basement complex. The second layer is characterized by water-saturated, weathered and fractured basement with model resistivity values of 45.1$346.2 \Omega \mathrm{m}$ from the vertical electrical resistivity soundings, which is in agreement with classification of moderately weathered/fractured basement with resistivity ranging from 100 to $800 \Omega \mathrm{m}$ as good groundwater aquifer within the Nigerian basement complex [10]. The aquiferous zone is underlain by the fresh basement with very high model resistivity values in the range of 1013.7-33,124.0 $\Omega \mathrm{m}$.

\section{Conclusions}

Geologically constrained vertical electrical soundings have been used to evaluate the groundwater potential in a crystalline basement terrain and to delineate target locations for sitting boreholes in the study area. The analyses of the sounding resistivity models clearly show three geoelectric layers; top layer, which is inferred to be sandy clayey/clay; water-saturated weathered and fractured basement with clayey materials serving as the aquifer unit; and fresh basement. The electrical soundings delineate higher bottom depth for the water-saturated aquiferous unit. The rigoliths (weathered basement) unit within the area with a bottom depth up to $42 \mathrm{~m}$ from the VES results. Thus, groundwater exploration and development in the area should target the weathered and fractured basement layer.

Acknowledgements The authors appreciate the Centre for Research, Innovation and Discovery (CUCRID) of Covenant University, Nigeria for conference support.

\section{References}

1. Olayinka, A.I., Weller, A.: The inversion of geoelectrical data for estimating aquifer hydrogeological applications in crystalline basement areas of Nigeria. J. Appl. Geophys. 37(2), 103-105 (1997)

2. Adepelumi, A., Ako, B., Ajayi, T.: Groundwater contamination in the basement complex area of Ile-Ife, southwestern Nigeria. Hydrogeol. J. 9(6), 611-622 (2001)

3. Ehinola, O.A., Opoola, A.O., Adesokan, H.A.: Empirical analysis of electromagnetic profiles for groundwater prospecting in rural areas of Ibadan, southwestern Nigeria. Hydrogeol. J. 14(4), 613624 (2006) 
4. Aizebeokhai, A.P., Oyeyemi, K.D.: The use of the multiple gradient array for geoelectrical resistivity and induced polarization imaging. J. Appl. Geophys. 111, 364-375 (2014)

5. Aizebeokhai, A.P., Oyeyemi, K.D.: Application of geoelectrical resistivity imaging and VLF-EM for subsurface characterization in a sedimentary terrain, southwestern Nigeria. Arab. J. Geosci. 8(6), 4083-4099 (2015)

6. Aizebeokhai, A.P., Oyeyemi, K.D., Joel, E.L.: Groundwater potential assessment in a sedimentary terrain southwestern Nigeria. Arab. J. Geosci. 9, 110-117 (2016)

7. Aizebeokhai, A.P., Oyeyemi, K.D., Noiki, F.R., Etete, B.I., Arere, A.U.E., Eyo, U.J., Ogbuehi, V.C.: Geoelectrical resistivity data sets for characterization and aquifer delineation in Iyesi, southwestern Nigeria. Data. Brief 15, 828-832 (2017)

8. Aizebeokhai, A.P., Oyeyemi, K.D.: Geoelectrical characterization of basement aquifers: the case of Iberokodo, southwestern Nigeria. Hydrogeol. J. 26(2), 651-664 (2018)

9. Kumar, D.: Efficacy of electrical resistivity tomography technique in mapping shallow subsurface anomaly. J. Geol. Soc. India 80, 304-307 (2012)

10. Olayinka, A.I., Amidu, S.A., Oladunjoye, M.A.: Use of electromagnetic profiling and resistivity sounding for groundwater exploration in the crystalline basement area of Igbeti, southwestern Nigeria. Global J. Geol. Sci. 2(2), 243-253 (2004) 